\title{
Learning Media Development Using Lectora Inspire for Social Science Subjects
}

\author{
Susi Astriani ${ }^{1)}$,Indri Astuti ${ }^{2)}$,Aloysius Mering ${ }^{3)}$ \\ 1)2)3) Tanjungpura University \\ 1) longantri1989@gmail.com ${ }^{2)}$ Indri astuti@ fkip.untan.ac id ${ }^{3)}$ aloysiusmering@fkip.untan.ac.id
}

Submitted : Jan 1, 2022 | Accepted : Jan 15, 2022 | Published : Jan 20, 2022

\begin{abstract}
This research refers to the research and development (R\&D) design, meaning the research method used to produce the product and then test the effectiveness of the product. The main objective of this research is to develop learning media by looking at the validity, and effectiveness of Lectora inspire learning media. The development of learning media using Lectora inspire is based on the Dick and Carey model of learning design. The development procedure used by considering the usability of the product. In the trial of Lectora Inspire-based learning media for social studies learning that has been validated by experts, it was carried out 3 times, namely: one to one trial, small group trial, and large group trial. The object of this research is the learning media of human life in the pre-literacy period with the subject of the research being class VII students of SMPN 6 Satap Galing. Technical data collection using direct observation studies, documentary in the form of distributing questionnaires. Data analysis techniques using qualitative and quantitative. This research was conducted on seventh grade students of SMP Negeri 6 Satap Galing, Sambas Regency for the 2019/2020 academic year as research subjects. The development of this learning media is carried out using the Borg and Gall development and the Dick and Carey development design model. The results of the development of the learning media that have been developed, in this case the product developed is the Lectora inspire learning media, and will explain the procedures that have been carried out.
\end{abstract}

Keywords: development, lectora inspire, student response,Social Education, Historical

\section{INTRODUCTION}

Learning is the process of learning and teaching done by a group of people somewhere that is done through various means. Various other technologies and applications have also been developed to facilitate teaching and learning activities. Along with the development of science and technology today, a teacher should be able to carry out learning by utilizing technology. One way is to prepare a learning medium that can attract student motivation to learn so that the material taught will be easier to understand. Media has an important role in the learning process because with the availability of adequate media will help teachers and students in facilitating the learning process so that the learning goals that have been set can be achieved.

(Machado 2020) who said that "technology advances have made possible the combination and coordination of herbal resentation modes (such as narration and on-screen text) with nonverbal presentation modes (such as graphichs, video, animations, and environmental sounds) in juts on device (the computer). The use of learning media in the classroom is very helpful for teachers in growing students' learning interests. By using the learning media learners will be more easily aroused thinking. In addition, the learning media is able to provide a clearer picture to learners about the material being studied. The use of interactive learning media can no longer be denied has become an important thing in the learning process.

Based on the results of observations and interviews conducted with students at Sambas District 6 Satap Galing State Junior High School, information was obtained that students do not like to study IPS because the material is many and difficult to understand. This is evidenced by the results of daily activities that are still low and strengthened from the results of odd semester IPS subject values that show that as many as $25 \%$ of 44 learners who average their raport results above 80 , while $75 \%$ of students are under 80 out of the total number of students 44 learners.

Based on this, there needs to be a learning media that can grow their interest in being enthusiastic in undergoing the learning process and apat supports the teaching and learning process and can be used as an alternative learning resource for learning independently by students. Therefore, the effort that can be done is to develop one of the learning media, namely learning media using lectora Inspire. Lectora inspire is an e-learning development software

*name of corresponding author 
that is relatively easy to apply because its use does not require a sophisticated understanding of programming languages (Shalikhah 2017)

According to (Nursidik and Suri 2018) ICT-based teaching media with Lectora Inspire application allows optimization of the involvement of all senses students can present a display in the form of text and multidimensional with interactive conclusions. The display can make users (users) more freely choose, and elaborate the knowledge they want to understand. By self-study students should try to understand the content of the material outside the classroom on their own, find their own sources of information and solve their own difficulties (Lubis 2020). Learning media is designed and developed using lectora inspire with to attract the interest of learners. Therefore, researchers will conduct research with the title "Development of learning media for social science subjects in class VII of State Junior High School 6 One Roof Galing".

\section{Understanding Learning}

\section{LITERATURE REVIEW}

Learning is a natural process that encourages change in the individual. These changes include aspects of knowledge( knowledge), skills (skills), and attitudes (attitudes). After going through the learning process, a person will generally be more knowledgeable, more skilled, and able to show a more positive attitude in living life (Camilleri and Camilleri 2020; Mahfudy et al. 2019; Munir 2009; Sukmadinata 2007)

The above opinion according to (Hooker 2017)) interprets learning as a process to change behavior so that knowledge and skills are obtained to be better than before. Learning is essentially a "change" that occurs within a person after performing a certain activity. Although in essence not all changes including the category of learning and can be interpreted that learning is a process of behavior change as a result of inter-individual interaction with environment.

From several understandings of learning from experts can be concluded learning is a change in cognitive, affective and psychomotor behavior that occurs in learners obtained from experience factor. Such changes are positive in the sense of being oriented in a more advanced direction than the previous state. But to get optimal results, the learning process must be done consciously and deliberately and well organized and neat.

\section{Media Learning}

Media is a means of learning used to facilitate learning activities. Media is intended as an intermediary for teachers and learners to create a learning process for learners, so that it can be used as a source of learning and help learners to learn. effectively, efficiently and attractively during the teaching and learning process.

Media is "the introduction of messages from sender to receiver of messages, thus media is the channeler of learning information or the distributor of messages. This is in line with the opinion of Suryani, et al (2018: 2), the media is, "everything that can be used to channel messages and can stimulate the mind, raise spirits, attention and the willingness of students so that it can encourage the occurrence of learning processes in students." According to (Jusuf 2017) the medium of learning can be interpreted as something that brings information and knowledge that can be learned by students.

The use of learning media can facilitate students to achieve desired goals or competencies. By using the learning medium all the five senses students can be used in their entirety, both through hearing, vision, and also touch. The availability of media in learning is expected to reduce the impression on the mind of students that teachers as the only source of information for students. The use of learning media as a tool during the learning process can help realize the success of the teaching and learning process (Jusuf 2017).

One of the images that are widely used as a reference in the use of media in a learning process can be presented in Dale's Cone of Experience (Dwyer 2010) in Figure 1 below.

THE

LEARNING PYRAMID

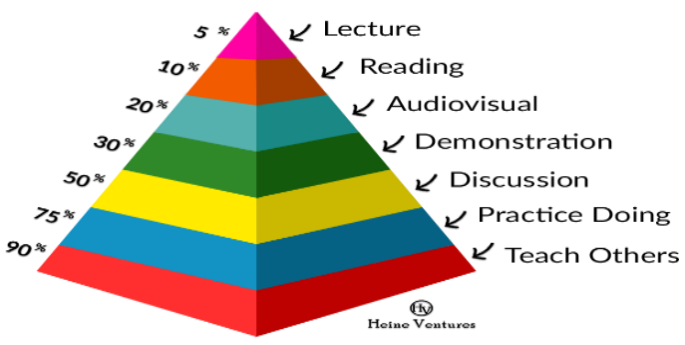

Gambar 1. Dale's Cone of Experience

\footnotetext{
*name of corresponding author
} 
Advantages in developing learning media using multimedia development are the ability to integrate text, graphics, animated images and videos. This leads to the ability to convey information, knowledge with a high level of realism. Later in the learning process can improve learning outcomes with the use of relatively little time and cost.

\section{Understanding Lectora Inspire}

According to Wikipedia Indonesia, Lectora is an Authoring Tool for e-learning content development developed by Triviants Corporation. Lectora can be used to create online training courses, assessments, presentations, and can convert presentations from Microsoft powerpoint into elearning content. Lectora is very easy to use in developing Interactive Learning Multimedia content.

Lectora is an authoring tool for e-learning content development developed by Triviants Corporation. Lectora can be used to create online training courses, assessments, presentations, and can convert presentations from Microsoft power points into e-learningcontent. Lectora is very easy to use in developing interactive learning multimedia content can be used to combine flash,video recording, combining images and screen capture.

Lectora allows users to create evaluations with various combinations. Evaluation questions available in lectora software include right wrong, multiple choice, matchmaking, drag and drop, essays and short answer questions. Lectora Inspire is specifically designed for beginners, so this software is very easy to use in the creation of learning media. Lectora learning media can be used offline or without having to install lectora software. This is because the final product of lectora-based learning media can be published into the form of Single File Executable with .exe file format.

\section{METHOD}

This research refers to the design of research and development (R\&D), meaning the research method used to produce the product and then test the effectiveness of the product. According to (Putra et al. 2020), define development research as follows: "Educational Research and Development (R\&D) is an industry bassed development model in which the findings of research are used to design new products and procedures which then are systematically field-tested, evaluated and refined until they meet specified criteria of effectiveness, quality, or similar standards." Research and development is a basic model of industrial development in which research discoveries are used to design new products and procedures that are systematic, evaluative, and filtered until specific criteria are found that are effective, qualified or have the same standards.

In this study, the development of the lectora inspire learning media is based on the learning design of the Dick and Carey model. This development research is generally divided into three stages: the pre-development stage, the product development stage and the trial \&revision stage. Development procedures carried out through 3 steps or 1) pre-development stages include: Identify instructional goal(s) to design general objective learning and curriculum, Conducting Goal Analysis to conduct learning analysis, Identity Entry Behavior's Characteristic to find out student characteristics and learning context, Write Performance Objectives to formulate The purpose of learning is based on material analysis. 2) The product development stage is carried out by 3 expert assessment people, namely media experts, material experts and learning practitioners, including: Develop Criterion Reference Test to develop assessment tools or instruments that are able to measure the achievement of knowledge on IPS lessons in learners, Develop Instructional Strategy to Develop Learning Strategies, Develop and Select Instructional Materials to develop learning that has been designed in previous stages into teaching materials to be used. Design And Conduct Formative Evaluation to collect data related to the strengths and weaknesses of lectora inspire-based learning media drafts for IPS learning, Revise Instructional to revise the draft of lectora inspirebased learning media for IPS learning. 3) Trial, Revision and Evaluation Conducted as many as 3 times, namely one to one trials, medium group trials and field trials.

The subject of research in The Development of Learning Media To the student's response here is in class VII SMPN 6 SATAP Galing numbered 30 students. Techniques and data collection tools use direct observation techniques using observation sheets, this direct communication technique uses tools in the form of interview sheets while documentary study techniques use tools that are documentation.

Validation of learning media is carried out by experts in their respective fields, namely: design experts, material experts and media experts. The learning media created and developed are as follows:

1) Recapitulate the results of expert assessments into tables that include: aspects and total values for each validator $(\overline{A I})(\overline{V l})$

2) Determines the average validation values of all validators for each criterion with the formula:

*name of corresponding author 


$$
\overline{K l}=\frac{\sum_{j=i}^{n} \overline{V l \jmath}}{n}
$$

Information:

$\overline{K l} \quad=$ Average criteria to $-\mathrm{i}$

$\overline{V l j} \quad=$ the value of the results of the assessment of the $\mathrm{i}$-criterion by the jth validator $\mathrm{n}=$ Number of validators

3) Determines the average values for each aspect with the formula:

Information:

$$
\overline{A \iota}=\frac{\sum_{j=i}^{n} \overline{K \iota}}{n}
$$

$$
\begin{array}{ll}
\overline{A l} & =\text { average value for the } \mathrm{i} \text {-aspect } \\
\bar{K} \iota \mathrm{J} & =\text { average for the } \mathrm{i} \text { aspect of the } \mathrm{j} \text {-criterion } \\
\mathrm{n}=\text { number of criteria }
\end{array}
$$

4) Search for total averages with formulas: $(\overline{V A})$

Information:

$$
\overline{V A}=\frac{\sum_{i=1}^{n} \overline{A l}}{n}
$$

$$
\begin{aligned}
& \overline{V A} \quad=\text { Total average } \\
& \overline{V A}=\text { Rata-average } \mathrm{i} \text { aspect } \\
& N=\text { Many aspects }
\end{aligned}
$$

5) Determine the validity category of each criterion or aspect average or total average with a predefined validation category. $(\overline{K I})(\overline{A I})(\overline{V A})$

Table 1.1 Learning MediaValidan Level Criteria

\begin{tabular}{cc}
\hline Value & Criterion \\
\hline $3.5 \leq$ in $\leq 4$ & Very valid \\
\hline $2,5 \leq V<3,5$ & Valid \\
\hline $1,2 \leq V<2,5$ & Valid enough \\
\hline $0 \leq V<1,5$ & Tidak valid \\
\hline
\end{tabular}

Information:

$\mathrm{V}=$ the averagevalidity value of all validators.

Analysis of student response assessment data is carried out after the observer fills out the observation sheet at the time of the learning activity. Activities carried out to calculate the data of student response observation sheets are: 1) assess the assessment of observer results, 2) create and analyze the table of observation results,3)calculate the number of assessment results on each aspect on criteria4 SS, S, RR, TS, STS each item or question and 4) calculate the total score of each aspect for all students with the formula:

Information:

$$
R S_{\text {media }}=\frac{\sum P_{j s}}{n}
$$

Media $_{\mathrm{rs}}=$ Average number of responses per learner for each questions after using the learning media

$\mathrm{P}_{\mathrm{js}} \quad=$ Point of choice of learners' answers for each question item $\mathrm{n}=$ Number of learners

Calculate the percentage of the average number of student response scores for each statement.

Information:

$$
\% R S_{\text {media }}=\frac{R S_{\text {media }}}{4} \times 100 \%
$$

$\% \mathrm{RS}_{\text {media }} \quad=$ Percentage of the average number of student response scores per learner for each question after using the learning media. 
Table 1.2 Test Response Questionnaire Score Interpretation

\begin{tabular}{ccccc}
\hline Shoes & $\begin{array}{c}\text { Level of } \\
\text { Achievement } \\
(\%)\end{array}$ & Qualification & \multicolumn{2}{c}{ Description of Student Response } \\
\cline { 3 - 5 } & & $\begin{array}{c}\text { Positive } \\
\text { Statement }\end{array}$ & $\begin{array}{c}\text { Negative } \\
\text { Statement }\end{array}$ \\
\hline 5 & $80<X \leq 100$ & Very Agree & Very Agree & $\begin{array}{c}\text { Strongly } \\
\text { Disagree }\end{array}$ \\
\hline 4 & $60<X \leq 80$ & Agree & Agree & Disagree \\
\hline 3 & $40<X \leq 60$ & Simply Agree & Nervous & Nervous \\
\hline 2 & $20<X \leq 40$ & Disagreement & Disagree & Agree \\
\hline 1 & $0 \leq X \leq 20$ & Disagree & Strongly & Very Agree \\
& & & Disagree & \\
\hline
\end{tabular}

RESULT

This development research produces products in the form of media lectora inspire for IPS learning eyes equipped with instructions for the use of media, as well as RPP as a reference for learning. This medium was developed to facilitate teachers to teach class VII students to learn independently. The development of this lectora inspire learning media has passed several stages of validity trials consisting of material content expert tests, media design expert tests, learning media expert tests, individual trials, small group trials, and field tests. The results of the expert test can be seen as follows:

Table 1. 3 Results of Media Expert Validation

\begin{tabular}{ccccl}
\hline No & Aspects & $\begin{array}{c}\text { Number of } \\
\text { Scores }\end{array}$ & Average & Category \\
\hline 1 & Letter & 22 & 3.67 & Very valid \\
\hline 2 & Operation & 27 & 3.86 & Very valid \\
\hline 3 & Voice & 19 & 3.8 & Very valid \\
\hline 4 & Display & 30 & 3.75 & Very valid \\
\hline & Overall average & & $3.77 \leq$ In $\leq 4$ & Very valid \\
\hline
\end{tabular}

Overall validation results by media experts based on overall aspects were obtained an average of 3.77 and fall into the category "Very Valid" used as a learning medium.

Table 1.4 Material Validation Results

\begin{tabular}{ccccc}
\hline No & Aspects & Number of Scores & Average & Category \\
\hline 1 & Learning Aims & 23 & 3.83 & Highly Valid \\
\hline 2 & Content Eligibility & 35 & 3.89 & Highly Valid \\
\hline 3 & Language & 18 & 3.6 & Highly Valid \\
\hline & Presentation of Materials & 19 & 3.8 & Highly Valid \\
\hline \multicolumn{3}{c}{ Overall Average } & $3.78 \leq$ In $\leq 4$ & Highly Valid \\
\hline
\end{tabular}

Based on the table it is known that the media developed as a whole validation results by material experts based on the whole of all aspects obtained an average value of 3.78. The results showed that the learning medium lectora inspire based on expert validation of the material belongs to the category "Very Valid" used as a learning medium.

Table 1.5 Validation results of learning design experts

\begin{tabular}{ccccc}
\hline No & Aspects & Number of Scores & Average & Category \\
\hline 1 & Display & 26 & 3.71 & Highly Valid \\
\hline 2 & Facilities & 15 & 3.67 & Highly Valid \\
\hline 3 & Benefits & 22 & 3.75 & Highly Valid \\
\hline 4 & Physical Application & 29 & 3.63 & Highly Valid \\
\hline \multicolumn{7}{c}{ Overall average } & & $3.69 \leq \mathrm{In} \leq 4$ & Highly Valid \\
\hline
\end{tabular}

*name of corresponding author 
Overall validation results by learning practitioners based on the whole all earned an average of 3.69 and fall into the category "Very Valid" is used as a medium of learning and deserves to be tested to students. In the individual trial stage(one to one) thetest subject consisted of 3 learners housed in class VII SMPN 6 Satap Galing. The results of the one to one group trial are as follows:

Table 1.6 One To One Trial Results

\begin{tabular}{ccccc}
\hline No & Aspects & Number of Scores & Average & Category \\
\hline 1 & Learning & 28 & 93.3 & Very Agree \\
\hline 2 & Material & 27 & 90 & Very Agree \\
\hline 3 & Bahsa & 26 & 86.6 & Very Agree \\
\hline 4 & Display & 27 & 90 & Very Agree \\
\hline 5 & Question & 26 & 86.6 & Very Agree \\
\hline \multicolumn{2}{c}{ Overall average } & $89.3 \%$ & Very Worthy \\
\hline
\end{tabular}

Based on the table above when viewed from the aspect of learning Overall the results of the one to one group trial obtained an average of $89.3 \%$ and fall into the category "Very Worthy" used as a learning medium.

In the individual trial stage, the Small Group of trial subjects consisted of 9 learners housed in class VII SMPN 6 Satap Galing. The results of the Small Group group trial are as follows:

Table 1.7 Medium ResPon Trial

\begin{tabular}{|c|c|c|c|c|}
\hline No & Aspects & Number of Scores & RataRata & Category \\
\hline 1 & Learning & 84 & 93.3 & Very Agree \\
\hline 2 & Material & 83 & 92.2 & Very Agree \\
\hline 3 & Bahsa & 83 & 92.2 & Very Agree \\
\hline 4 & Display & 86 & 95.5 & Very Agree \\
\hline 5 & Question & 82 & 91.1 & Very Agree \\
\hline \multicolumn{3}{|c|}{ Overall average } & $92.86 \%$ & Very Agree \\
\hline
\end{tabular}

Based on the table above when viewed from the aspect of learning Overall the results of moderate group trials by learners obtained an average of $92.86 \%$ and fall into the category "Strongly Agree" used as a medium of learning. In the trial stage, the Large Group of trial subjects consisted of 30 learners housed in class VII SMPN 6 Satap Galing. The results of the Large Group group trials are as follows:

Table 1.9 Field Trial Student Assessment Results

\begin{tabular}{ccccc}
\hline No & Aspects & Number of Scores & Average & Category \\
\hline 1 & Learning & 290 & 96.66 & Very Agree \\
\hline 2 & Material & 290 & 96.66 & Very Agree \\
\hline 3 & Language & 292 & 97.33 & Very Agree \\
\hline 4 & Display & 291 & 97 & Very Agree \\
\hline 5 & Question & 285 & 95 & Very Agree \\
\hline \multicolumn{2}{c}{ Overall average } & $96.53 \%$ & Very Agree \\
\hline
\end{tabular}

Based on the results of field trials on learning media through lectora inspire as stated in the table above, the results of calculations when viewed from the overall learning aspect of learning assessment results by learners were obtained an average of $96.53 \%$ and fall into the category of "Strongly Agree" as a learning medium for students of class VII SMPN 6 Satap Galing. Thus, the materials and media used in learning media using lectora inspire are expressed very well and can be used.

\section{DISCUSSIONS}

The initial process of developing interactive media products based on Lectora Inspire on IPS subjects of human life material in pre-ascetic times in class VII through initial product planning by making observations to the school, namely SMP Negeri 6 Satap Galing. Based on the results of observations then analyzed that SMP Negeri 6 Satap Galing in the learning process, especially IPS, dominated the use of print media or printed books, so that the time in the delivery of material was less maximally utilized and ultimately had an impact on learners. In addition, in the learning process without any variation in learning so that learning becomes less interesting.

*name of corresponding author 
Facilities supporting the learning process in school are adequate such as the availability of computers / laptops and computer rooms, LCD / projectors that can be utilized in the learning process.

\section{Learning Media Development Design}

The process of developing lectora inspire learning media using the dick and carey development model consists of three stages, namely pre-development, development, and trial, revision and evaluation. The stages are carried out starting from the initial analysis that aims to find out and establish the basic problems faced in the learning process.

Then conduct an analysis of learners to find out the characteristics of learners obtained through observation and analysis of materials aimed at identifying, detailing and compiling the main materials that will be studied by learners. To formulate learning goals that must be achieved by learners, task analysis and analysis of learning goals, the analysis of subsequent goals becomes the basis for the preparation of tests and designing learning media to be developed. Next prepare a prototype of the learning media. This stage consists of 3 steps, namely: (1) Preparation of tests. This test is a tool to measure the achievement of learners' learning outcomes, (2) Selection of media that fit the learning objectives, which will be used when the learning process has taken place, (3) Format selection, determining the format of learning media. The next stage is the stage of learning media development. This stage is the last stage that evaluates learning media through several processes, namely: expert validation, revision, and media trials so that valid, practical, and effective learning media is produced.

Based on the results of the analysis, researchers have the idea to develop an Interactive Learning Media Based on Lectora Inspire. The Design Stage of researchers discusses media that include the creation of learning media design concepts (storyboard), the preparation of materials, questions and answers, and the creation of backgrounds, images, characters and backsound. The concept of Lectora Inspire-based Interactive Learning Media in the form of materials, examples of questions and discussions and evaluation problems in accordance with (KI) and $(\mathrm{KD})$ learning.

The 2013 curriculum, when examined has been adapted to the characteristics of gen Z, among others: digitalnavites, screenteers, gamers, zeds, intelligent technology, connected in life on earth planet, world changer and "follow the heart", then it is necessary to design historical learning that suits their needs Learning design that can optimize needs and meet their learning desires.

In the context of historical learning, historical learning design designed by educators should be able to facilitate learners in taking meaning from historical events, as well as learning videos. The material in the program is in accordance with what is expected in the curriculum but equipped with various interesting features in it so as to allow learners to receive the subject matter more easily and interestingly. Learning media can be used if the media supports the achievement of instructional goals that have been formulated and in accordance with the nature of the instructional matreri that has been formulated.

Furthermore, the selection of formats in this case aims so that the format is designed in accordance with the curriculum, indicators, learning objectives and learning materials so that the presentation is more neatly arranged. The presentation of the format used in the preparation of learning media consists of a cover format, instruction format, preliminary format, content format (consisting of learning materials and videos), final format (exercises and bibliography) and cover format (profile) packaged in compact disk (CD). Compact Disk (CD) assisted interactive learning media can improve students' learning outcomes and interests. researchersdevelop interactive learning mediathat sulk at the syllabus and are expected to be new innovations with the aim of improving learning outcomes and interests of learners, so that learners get a real picture of the material as well as ease in understanding learning materials.

\section{Learning media development procedures}

The procedure of learning media development is an activity undertaken to compile, write and test the readability and feasibility of the initial design of learning media. Development phase of interactive learning media development, all components such as background design, images, characters, navigation buttons, audio, material materials and problems prepared using Lectora Inspire V. 17 software in accordance with storyboard design. The final product of learning media development is an offline file published in .exe format so that it can be used on the user's computer or laptop without having to install lectora inspire first.

The suitability of interactive learning media developed with the characteristics of media learning is strengthened by opinions by material experts to obtain results on aspects of learning objectives obtained an average value of 3.83. in the aspect of eligibility content obtained an average value of 3.89. In the language aspect obtained an average value of 3.6. In the presentation aspect obtained an average value of 3.8. The results of expert opinion material showed that in general each aspect obtained an average value of $3.78 \leq \mathrm{V} \leq 4$ which are in the valid category (see in appendix D.I page)

*name of corresponding author 
This is because in the aspect of media content / material is in accordance with the existing RPP, in addition the delivery of material is presented in the form of text, images, audio and video to clarify the material. This technological concept is like that in research conducted by (Andi Sumardji, 2015) by using lectora to present text, images and problems in developed learning media.

Lectora Inspire-Based Interactive Learning Media then validated by learning media experts obtained results on the aspect of letters obtained an average score of 3.67. in the operating aspect obtained an average value of 3.86. in the sound aspect of the average score of 3.8. And on the display aspect obtained an average value of 3.75. Based on the results of each aspect in a broad manner, the average opinion on the product by learning media experts shows an average value of $3.77 \leq \mathrm{V} \leq 4$ in the valid category (see in appendix D.1 page.

Lectora Inspire Learning Media is then validated by learning design experts obtaining results on the Display aspect obtained an average score of 3.71. in the ease aspect obtained an average value of 3.67. in the aspect of expediency in the average value of 3.75. And on the physical aspect of the application obtained an average value of 3.63. Based on the results of each aspect in a broad manner, the average opinion on the product by learning design experts showed an average value of $3.69 \leq \mathrm{V} \leq 4$ which are in the valid category.

The results of the analysis of these three experts obtained results with an average value of 3.75 and entered into the criteria "very valid". Based on these results, interactive learning media based on Lectora Inspire can be used as an IPS learning medium because the product is in accordance with the material taught. This suggests that the developed Lectora Inspire media is feasible for use in IPS learning.

The one to one trial phase of 3 learners in class VII at SMP Negeri 6 Satap Galing Sambas Regency is known to be the result of learning aspects with an average score of 93.3, material aspects with an average score of 90 , language aspects with an average score of 86.6, display aspects with an average score of 90 . And for the problem aspect with an average value of 86.6.

Based on the results of the recapitulation of the one-to-one trial assessment obtained an overall average score of 89.3 with the category "Very Feasible", meaning that the one to one Trial of Interactive Learning Media Based on Lectora Inspire is already good to meet the needs of learners, the use of language that clearly makes learners interested in trying to operate and qualify field trials.

The implementation of the trial of a group of 9 learners in class VII in SMP Negeri 6 Satap Galing Sambas Regency obtained the results of learning aspects with an average score of 93.3, material aspects with an average score of 92.2, language aspects with an average value of 92.2, display aspects with an average score of 95.5. And for the problem aspect with an average value of 91.1.

So that the average field test assessment obtained results with a percentage of 92.86 and entered the agreed criteria (Feasible). This means that small group trials of Lectora Inspire-Based Interactive Learning Media are good to meet the needs of learners, meaning that the Lectora Inspire-Based Interactive Learning Media developed has very decent criteria as a learning medium that can be used by learners in the learning process.

\section{CONCLUSION}

Learning Media Development using Lectora Inspire by combining the Dick and Carey development model is carried out through several stages, namely the analysis stage is the initial stage for the analysis of student needs and the analysis of the material for the learning media to be developed. The design phase consists of designing learning design concepts, material creation, answer questions and keys, as well as background selection, images, characters and backsound. At the design stage, researchers use prototypes to become products in the development stage. The final stage is a testing phase that includes due diligence from material experts, media, and small group tests. Once revised, the product can then be used in research classes. Lectora Inspire-Based Interactive Learning Media feasibility assessment obtained an average value of all aspects of 3.77 which falls into the category "Very valid" used as an IPS learning medium, based on Material Experts obtained an average value of all aspects of 3.78 which fall under the category "Very Valid" used as a learning medium, based on practitioner learning (design) obtained an average of all aspects of 3.69 which fall into the category "Very Valid" used as a learning medium, based on practitioner learning (design) obtained an average of all aspects of 3.69 which fall into the category "Very Valid" used as a learning medium, based on practitioner learning (design) obtained an average of all aspects of 3.69 which fall into the category "Very Valid" used as a learning medium, based on practitioner learning (design) obtained an average of all aspects of 3.69 which fall into the category "Very Valid" used as a learning medium, based on practitioner learning (design) obtained an average of all aspects of 3.69 which fall into the category "Very Valid" used as a learning medium, based on practitioner learning (design) obtained an average of all aspects of 3.69 which fall into the category valid" is used as an IPS learning medium. The student's assessment of Learning Media using Lectora Inspire in the one to one (3 student) group trial obtained an all-aspect average score of 89.3 which falls into the category "Very Decent". Assessment on moderate group Trials (9 students) obtained an all-aspect grade point average of 92.86 which falls into the category "Very Worthy". And

*name of corresponding author 
for assessment on field trials (30 students) obtained an average score average of 96 aspects which fall into the category "Very Decent".

\section{REFERENCES}

Camilleri, Mark Anthony, and Adriana Caterina Camilleri. 2020. "The Use of Mobile Learning Technologies in Primary Education.” 250-66. doi: 10.4018/978-1-7998-3250-8.ch013.

Dwyer, Francis. 2010. “Edgar Dale's Cone of Experience: A Quasi-Experimental Analysis.” International Journal of Instructional Media 37(4).

Hooker, C. 2017. "Mobile Learning Mindset." Arlington: International Society for Technology in ....

Jusuf, Heni. 2017. "Model Blended Learning Berbasis Teknologi Informasi Dalam Pembelajaran.” Jutisi 6(2).

Lubis, Juli Wahyuni. 2020. "Pengembangan LKPD Kecepatan Dan Debit Berbasis Lectora Inspire Terhadap Berpikir Kritis Di Sekolah Dasar." Jurnal Pendidikan Tambusai 4(3).

Machado, L. E. W. 2020. "Mobile Learning: Atitude De Estudantes Universitários Na Aprendizagem De Língua Estrangeira Sob A Perspectiva Ecológica.” Repositorio de Tesis y Trabajos Finales ....

Mahfudy, Sofyan, Kamirsyah Wahyu, Mauliddin Mauliddin, Lalu Sucipto, Erpin Evendi, and Samsul Irpan. 2019. "Characters and Values in Mathematics Teaching and Learning: A Review of Researches in Indonesia." Beta: Jurnal Tadris Matematika 12(1). doi: 10.20414/betajtm.v12i1.237.

Munir. 2009. "Definisi E-Learning ,Karakteristik, Manfaat Dan Fungsi E-Learning.” Alfabeta, Bandung (1999).

Nursidik, Hamidah, and Indah Resti Ayuni Suri. 2018. "Media Pembelajaran Interaktif Berbantu Software Lectora Inspire." Desimal: Jurnal Matematika 1(2). doi: 10.24042/djm.v1i2.2583.

Putra, Dede Dwiansyah, Ardo Okilanda, Arisman Arisman, Muhsana El Cintami Lanos, Siti Ayu Risma Putri, Mutiara Fajar, Hikmah Lestari, and Sugar Wanto. 2020. "Kupas Tuntas Penelitian Pengembangan Model Borg \& Gall." Wahana Dedikasi : Jurnal PkM Ilmu Kependidikan 3(1). doi: 10.31851/dedikasi.v3i1.5340.

Shalikhah, Norma Dewi. 2017. "Media Pembelajaran Interaktif Lectora Inspire Sebagai Inovasi Pembelajaran." Warta LPM 20(1). doi: 10.23917/warta.v19i3.2842.

Sukmadinata, Nana. 2007. "Definisi E-Learning.” Definisi E-Learning.

*name of corresponding author 